threne in mice have, within each species, tissue-specific antigens. The immunological reactions of the host against these tumours as detected in vitro are similar to those observed in man. Immunization by bladder cancer cells from mice of the same strain reduced the induction of bladder cancer by methylcholanthrene. This is an unexpected finding, because hitherto tumours induced by chemical carcinogens had individually unique antigens and did not cross-react with other tumours produced in a similar tissue by the same chemical. It will be of great interest to see if this observation holds true for bladder cancers induced by other bladder carcinogens and by oral as well as intravesical exposure to the agent.

1 Bubenik, J., Perlmann, P., Helmstein, K., and Moberger, G.; International

Fournal of Cancer, 1970, 5 , 39.
Bubenik, J., Perlmann, P., Helmstein, K., and Moberger, G., International Fournal of Cancer, 1970, 5, 310.

s Hellström, I., Hellström, K. E., Sjögren, H. O., and Warner, G. A., International fournal of Cancer, 1971, 7, 1 .

- Tanaka, T., Cooper, E. H., and Anderson, C. K., European fournal of Clinical and Biological Research, 1970, 15, 1084

5 Sarma, K. P., Fournal of Urology, 1970, 104, 843.

- Olsson, C. A., Rao, C. N., Menzoian, J. O., and Byrd, W. E., Fournal of Urology, 1972, 107, 607.

7 Taranger, L. A., Chapman, W. H., Hellström, I., and Hellström, K. E., Science, 1972, 176, 1337.

\section{P.H.L.S. Monographs}

The Public Health Laboratory Service has achieved a standard of diagnostic bacteriological work probably unsurpassed on such a scale in any other country. In a unified Service holding regular staff meetings it has been possible for directors of laboratories to exchange ideas about methods, some modifications of which, so far from having been published, have not even been committed to paper. It has therefore been decided to publish a series of monographs embodying this information for the benefit both of the Service and of other laboratories engaged in such work. Sir James Howiel writes in a preface to the first of these, on "Laboratory Diagnosis of Venereal Disease,": "During our discussions on preparing the series, it became evident that our half-hidden treasures included not only methods that were used within the P.H.L.S. but also fragments and even substantial bodies of unpublished scientific work which were taken for granted within the Service but which had never been made generally known." He also writes that the object is not to "duplicate or replace standard textbooks." In fact there are no books in which the best methods of performing particular investigations are so exhaustively described by authors with special experience of them. The nearest existing approach to this venture is the series of "Broadsheets" of the Association of Clinical Pathologists, which covers a much wider field in publications of a more condensed form.

The subjects of the first three of these monographs, now published simultaneously, will appeal in different ways and to different people. No. 1 , on the laboratory diagnosis of venereal disease, is naturally by $A$. E. Wilkinson and his colleagues of the Venereal Disease Reference Laboratory at the London Hospital, and includes a full description of five distinct serological tests for syphilis, some of which are unlikely to be attempted in most laboratories. More helpful to them is the very detailed account which follows, by D. A. McSwiggan and C. E. D. Taylor, of a "simplified" complement-fixation test. Methods for the diagnosis of gonorrhoea include instructions for two methods of determining penicillin sensitivity, of which the plate dilution method appears preferable to that employing discs. In the diagnosis of trichomoniasis emphasis is laid on the greater sensitivity of cultivation, for which the medium used contains chloramphenicol, gentamicin, and amphotericin. That recommended for growing gonococci contains vancomycin, colistin, and nystatin, with or without trimethoprim. The achievements of antibiotics in getting rid of unwanted bacteria in cultures are no less remarkable in their small way than their capacity to cure disease.

No. 2, on "The Use of Chemical Disinfectants in Hospitals," is by J. C. Kelsey and Isobel M. Maurer, and embodies the distilled experience gained since the establishment of the Disinfection Reference Laboratory under Kelsey in 1960. The preface to this refers to "the large number of written and oral inquiries" on this subject which reach the Service, and it is doubtless felt that in future such approaches can be met by simply referring the inquirer to this publication. It gives an account of the properties of different disinfectants, not omitting their costs, and some of their manifold uses. Instead of laying down the law themselves about optimum methods the authors have reproduced in full the "disinfectant policies" adopted by six hospitals or hospital groups, each giving instructions for the chemical disinfection of everything from baths to urinals in alphabetical order, among which the reader must evidently make his own choice. This can be somewhat varied; for heat-sensitive cystoscopes it lies between pasteurization, chlorhexidine, ethylene oxide, glutaraldehyde, and reference to Broadsheet No. 1 of the A.C.P. "Disinfectant testing in a hospital should be restricted to in-use testing"-that is, cultivation of solutions in use to determine whether they actually contain living bacteria, as they often do if overdiluted by ward staff or too seldom changed.

The subject of No. 3 is "Anaerobic Infections," by A. T. Willis. This gives an excellent account of methods of securing anaerobiosis, of culture media required for special purposes, and of the characters of Clostridia; a full-page table gives those of 19 "commonly encountered" species. It refers only briefly to the Gram-negative anaerobic bacilli (Bacteroides, etc.), and it would seem to be mainly to these to which the preface refers in writing of the "technical difficulties in their isolation and identification" and the "confused state of their taxonomy and nomenclature." In any future edition this section might with advantage be expanded.

\footnotetext{
Public Health Laboratory Service Monograph Series, Nos. 1-3 issued.
} London, H.M.S.O., 1972.

\section{Weightless Bones}

Patients who are bedridden for long periods suffer from, among other effects, loss of mineral matter from the bones. A similar effect results from prolonged weightlessness in space. Consequently, studies of it in astronauts may help people who lead more mundane lives.

At the recent International Astronautical Congress in Vienna $^{1}$ Dr. Stephen Hully, of the United States Public Health Service Hospital, San Francisco, described how he and three colleagues kept 34 healthy males in bed for periods varying from 17 to 36 weeks, allowing them to raise their 